\title{
Mutants for rice storage proteins. III. Genetic analysis of mutants for storage proteins of protein bodies in the starchy endosperm
}

\author{
By Toshihiro Kumamaru*, Hikaru Satoh**, Nobuo Iwata*, \\ Takeshi OMURA* and Masahiro OGAWA*** \\ *Plant Breeding Laboratory, Faculty of Agriculture, Kyushu University, \\ Hakozaki, Fukuoka 812 \\ **Kyushu University Farm, Harumachi, Kasuya, Fukuoka 811-23 \\ ***The Reseach Institute for Food Science, Kyoto University. \\ Uji, Kyoto 611
}

(Received April 16, 1987)

\begin{abstract}
Two mutants for rice storage protein in the starchy endosperm, 13b-L and 57-H, were crossed with their original variety, Kinmaze. From the results obtained in the $\mathrm{F}_{1}$ and $\mathrm{F}_{2}$ seeds, it was concluded that $13 \mathrm{~b}-\mathrm{L}$ and $57-\mathrm{H}$ are controlled by single recessive genes, which were designated as esp-1 and $e s p$-2, respectively. The SDS-PAGE indicates that both mutant genes are regulatory genes for the protein bodies. The segregation ratio in $F_{2}$ of the cross between $e s p-1$ and trisomic type $F$ and the cross between $e s p-2$ and trisomic type $\mathrm{G}$ fitted that of a trisomic segregation. These results suggest that $e s p-1$ and $e s p-2$ are located on chromosomes 10 and 9 , respectively.
\end{abstract}

Key Words: rice, mutant, storage protein, SDS-PAGE, gene analysis.

\section{INTRODUCTION}

There are a large number of genes for seed storage proteins in cereals. 02 (Opaque-2) is a regulatory gene (Soave et al. 1978) and some $Z p$ genes are structural genes for zein subunits (Lee et al. 1976, Soave et al. 1982) which are alcohol soluble proteins in maize endosperm. Hordein, the storage protein of barley grain, consists of three groups of polypeptides called B, C and D hordein. Each group is coded by a complex locus designated as Hor 2, Hor 1 and Hor 3, respectively (Blake et al. 1982, Faulks et al. 1981, Shewry et al. $1980,1983)$. The studies on chromosomal localization of the genes for gliadin and glutenin which are alcohol soluble and acid and/or alkaline soluble proteins of wheat endosperm, respectively, have also been done (Galili and Feldman 1984, Jackson et al. 1983, Payne et al. 1980, 1982, 1984).

In rice, Kataoka (1978) and Kambayashi et al. (1984) reported that the grain protein content is controlled by polygenes, but there are few studies on the major gene for grain protein. Tanaka et al. (1980) isolated and characterized two types of protein bodies from rice endosperm. One type of protein body 
(PB-I) was a spherical particle with lamellar structure 1-2 $\mu \mathrm{m}$ in diameter. The other type (PB-II) was stained homogeneously and had no lamellar structure. PB-I is the deposition site of prolamin and PB-II is that of glutelin. The polypeptide constitution of protein bodies can be distinguished by sodium dodecyl sulfate polyacrylamide gel electrophoresis (SDS-PAGE) analysis of crude protein extracted from rice endosperm. In previous studies, four types of mutants for storage proteins were selected and some of them have been evaluated as suitable breeding material of rice endosperm protein (Kumamaru et al. 1987). These were mutants in which the polypeptide composition in the protein bodies in rice endosperm were remarkably changed (Kumamaru et al. 1986). The present study deals witn the genetic behavior of the gene for each polypeptide in two mutant lines, and the identification of the chromosome on which these genes are located.

\section{MATERIALS AND METHODS}

Materials: Two mutant lines for seed storage protein, CM 21 and CM 1787, were used in this experiment. They were induced by N-methyl-N-nitrosourea from a rice cultivar, Kinmaze, and have been stocked at Plant Breeding Laboratory, Kyushu University and were screened by Kumamaru et al. (1987). CM 21 is a mutant which has a remarkably lower intensity of the $13 \mathrm{~b}$ polypeptide band and a slightly higher intensity of $57 \mathrm{kDa}$ polypeptide band than that of Kinmaze (Fig. 1). In CM 1787, the intensity of the $57 \mathrm{kDa}$ and 10-39 $\mathrm{kDa}$ polypeptide bands is higher and lower, respectively, than that of Kin-

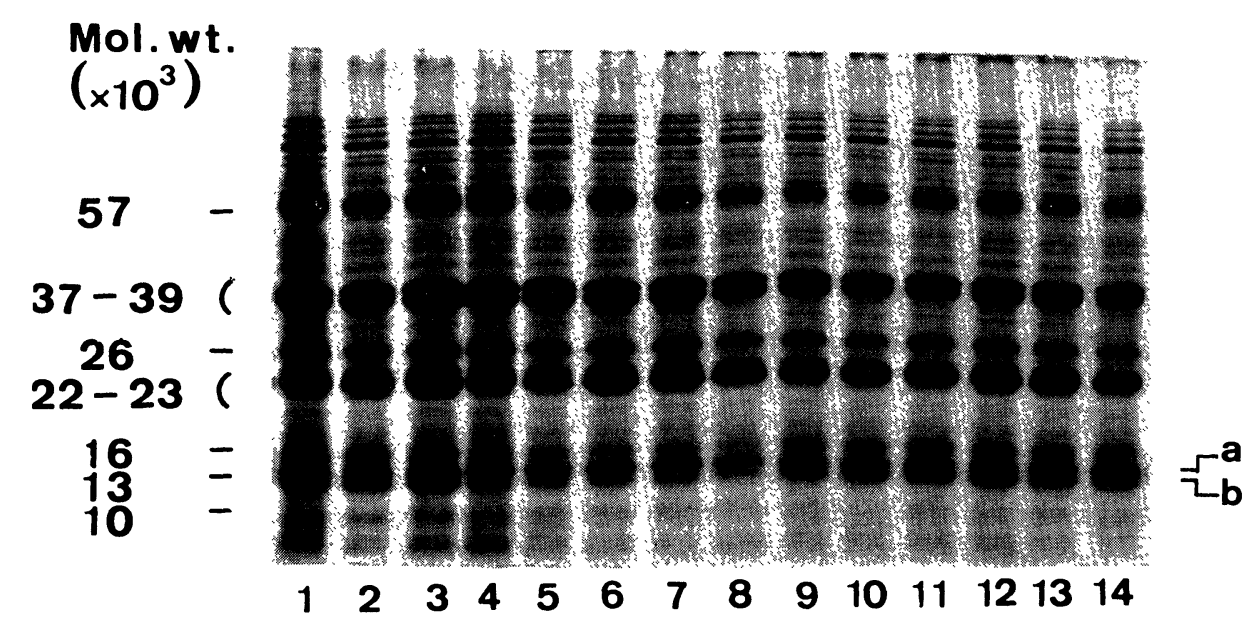

Fig. 1. SDS-PAGE of the storage protein in the $F_{1}$ and $F_{2}$ seeds of the cross between Kinmaze and CM 21.

1) Kinmaze, 2) $F_{1}$ seed of the cross between Kinmaze $\times \mathrm{CM} 21$, 3) $F_{1}$ seed of the cross between CM $21 \times$ Kinmaze, 4) CM 21, 5-8) CM 21 type (13b-L) in $\mathrm{F}_{2}$ seeds, 9-14) Kinmaze type (normal) in $\mathrm{F}_{2}$ seeds. 


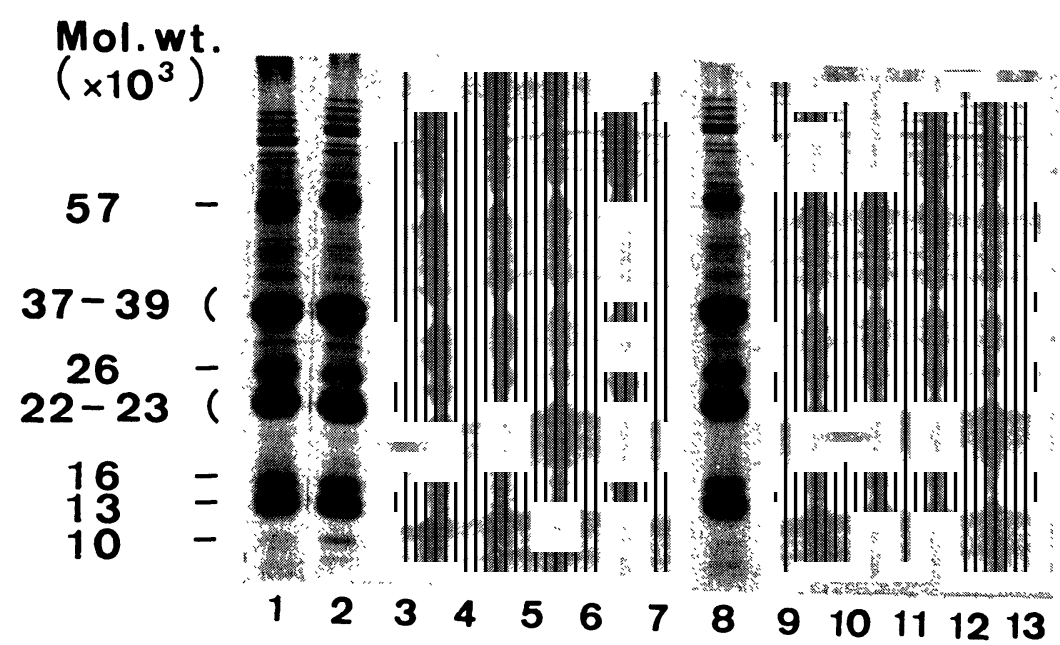

Fig. 2. SDS-PAGE of the storage protein in the $\mathrm{F}_{1}$ and $\mathrm{F}_{2}$ seeds of the cross between Kinmaze and CM 1787.

1) Kinmaze, 2) $F_{1}$ seed of the cross between Kinmaze $\left.\times C M 1787,3\right) F_{1}$ seed of the cross between CM $1787 \times$ Kinmaze, 4) CM 1787, 5-7) CM 1787 type (57-H) in $\mathrm{F}_{2}$ seeds, 8-13) Kinmaze type (normal) in $\mathrm{F}_{2}$ seeds.

maze (Fig. 2). Therefore, the mutant types of CM 21 and CM 1787 have been named 13b-L and 57-H, respectively (Kumamaru et al. 1987).

Cross: Reciprocal crosses were made between two mutant lines and Kinmaze. The proteins of $F_{1}$ seeds and $F_{2}$ seeds of each cross were analysed by SDSPAGE.

Trisomic analysis was applied to determine the chromosome on which the genes for storage protein mutants are located. The trisomic series used in this study have been derived from a desynaptic mutant induced from Kinmaze (Satoh unpublished). In the crosses of mutant lines with trisomic series, $\mathrm{F}_{1}$ plants were classified into disomic and trisomic plants based on their phenotypic expression, as reported by Iwata et al. (1970). The storage proteins of $\mathrm{F}_{2}$ seeds were analysed by SDS-PAGE.

Protein extraction: The individual seeds of $\mathrm{F}_{1}$ and $\mathrm{F}_{2}$ seeds were struck by hammer, and the tissue was then placed in a micro test tube $(1.5 \mathrm{ml})$ with $600 \mu \mathrm{l}$ of $0.125 \mathrm{M}$ Tris- $\mathrm{HCl} \mathrm{pH} 6.8$ containing $4 \%$ SDS, $8 \mathrm{M}$ urea, $5 \% 2$-mercaptoethanol and $20 \%$ glycerin and incubated for 4 hours at $30^{\circ} \mathrm{C}$. After centrifugation (5 min., 15,000 r.p.m.), the supernatants were applied to SDSPAGE.

$S D S-P A G E$ : Extracted storage proteins of $\mathrm{F}_{1}$ and $\mathrm{F}_{2}$ seeds were electrophoresed using the discontinuous buffer system of Laemmli (1970) on a slab 
gel and were stained by $0.05 \%$ Coomassie brilliant blue R-250 in $7 \%$ acetic acid and $50 \%$ methanol and destained by $7 \%$ acetic acid.

\section{RESULTS AND DISCUSSION}

Fig 1 shows the SDS-PAGE of the proteins of $F_{1}$ and $F_{2}$ seeds from the reciprocal crosses between Kinmaze and CM 21. SDS-PAGE patterns of both $F_{1}$ seed proteins were of the normal type, i.e., Kinmaze, and only two types, normal and $13 \mathrm{~b}-\mathrm{L}$, were segregated in $\mathrm{F}_{2}$ seeds, though the segregation of $57 \mathrm{kDa}$ polypeptide in $\mathrm{F}_{2}$ seeds is not clear. These results show that $13 \mathrm{~b}-\mathrm{L}$ is recessive to the normal and there is no gene dosage effect. The segregation mode in the $\mathrm{F}_{2}$ seeds of the cross between CM 21 and an original cultivar are shown in Table 1. The segregation ratio showed a good fit to the expected $3: 1$ ratio. The result suggests that the 13b-L in CM 21 is controlled by a single recessive gene.

Table 1. Segregation of normal and mutant types in $F_{2}$ seeds of the cross between Kinmaze and mutants

\begin{tabular}{rrrrrrr}
\hline \multirow{2}{*}{ Cross combination } & \multirow{2}{*}{$\begin{array}{c}\text { Phenotype of } \\
\mathrm{F}_{1} \text { seeds }\end{array}$} & \multicolumn{3}{c}{ Segregation in $\mathrm{F}_{2}$ seeds } & \multirow{2}{*}{$\chi^{2}(3: 1)$} \\
\cline { 4 - 5 } & Normal & Mutant & Total & \\
\hline Kinmaze $\times$ CM & 21 & Normal & 163 & 48 & 211 & 0.57 \\
$\times$ CM 1787 & Normal & 144 & 56 & 200 & 0.96 \\
\hline
\end{tabular}

Fig. 2 shows the SDS-PAGE of the protein of $F_{1}$ and $F_{2}$ seeds from the reciprocal crosses between Kinmaze and CM 1787. Both $F_{1}$ seeds showed the normal type, and the normal and 57-H types were segregated in the $\mathrm{F}_{2}$ seeds. Moreover, 57-H type always accompanied with lower intensity of 10-39 kDa polypeptides than that of Kinmaze. The concurrent change of these polypeptides may result from pleiotropic expression of gene for enriched $57 \mathrm{kDa}$ polypeptide or close linkage between gene for $57 \mathrm{kDa}$ and genes for 10-39 $\mathrm{kDa}$ polypeptides. The results show that, as with $13 \mathrm{~b}-\mathrm{L}$, this trait is recessive to the normal and there is no gene dosage effect. The segregation in the $\mathrm{F}_{2}$ seeds of the cross between CM 1787 and an original cultivar are shown in Table 1. The segregation ratio showed a good fit to the expected 3:1 ratio. The result suggests that $57-\mathrm{H}$ in $\mathrm{CM} 1787$ is controlled by a single recessive gene.

Trisomic analysis was applied to determine the chromosome on which these genes are located. The segregation pattern for $13 \mathrm{~b}-\mathrm{L}$ in the $\mathrm{F}_{2}$ seeds of the crosses between CM 21 and five trisomic types is shown in Table 2. In the cross with trisomic type $\mathrm{F}$, the segregation ratio of about $12: 1$ was observed 
in the $\mathrm{F}_{2}$ seed progenies from the trisomic $\mathrm{F}_{1}$ plant and fitted to the trisomic ratio between $8: 1$ and $44: 1$. The result suggests that the gene for $13 \mathrm{~b}-\mathrm{L}$ is located on an extra chromosome of trisomic type F. As the extra chromosome of type F corresponded to chromosome 10 (Iwata and Omura 1971, 1975), it was concluded that the gene for $13 \mathrm{~b}-\mathrm{L}$ is located on chromosome 10 .

Table 2. Segregation of normal and $13 b-L$ in $F_{2}$ seeds of trisomic $F_{1}$ plants derived from the crosses between trisomics and CM 21

\begin{tabular}{crrrr}
\hline \multirow{2}{*}{$\begin{array}{c}\text { Type of trisomics } \\
\text { (Chromosome) }\end{array}$} & \multicolumn{2}{c}{ Segregation in $\mathrm{F}_{2}$ seeds } & \multirow{2}{*}{$\chi^{2}(3: 1)$} \\
\cline { 2 - 5 } & Normal & $13 \mathrm{bL}$ & Total & \\
\hline F (10) & 190 & 16 & 206 & $32.63^{* * *}$ \\
A ( 4) & 41 & 9 & 50 & 1.31 \\
E (11) & 39 & 11 & 50 & 0.24 \\
H ( 1) & 41 & 9 & 50 & 1.31 \\
L (2) & 36 & 11 & 47 & 0.06 \\
\hline
\end{tabular}

***: Significant at $0.1 \%$ level.

CM 1787 (57-H) was crossed with trisomic types B, C, D, E, F and G. The results are shown in Table 3 . In the cross with type $G$, the segregation ratio was about $13: 1$ and significantly deviated from the $3: 1$ ratio. As the extra chromosome of type G corresponded to chromosome 9 (Iwata and Omura $1971,1975)$, it was concluded that the gene for $57-\mathrm{H}$ is located on chromosome 9.

Table 3. Segregation of normal and $57-\mathrm{H}$ in $\mathrm{F}_{2}$ seeds of trisomic $F_{1}$ plants derived from the crosses between trisomics and CM 1787

\begin{tabular}{ccccc}
\hline \multirow{2}{*}{$\begin{array}{c}\text { Type of trisomics } \\
\text { (Chromosome) }\end{array}$} & \multicolumn{2}{c}{ Segregation in $\mathrm{F}_{2}$ seeds } & \multirow{2}{*}{$\chi^{2}(3: 1)$} \\
\cline { 2 - 4 } & Normal & $57-\mathrm{H}$ & Total & \\
\hline G ( 9) & 186 & 14 & 200 & $34.56^{* * *}$ \\
B (6) & 38 & 12 & 50 & 0.03 \\
C ( 7) & 40 & 10 & 50 & 0.67 \\
D (12) & 42 & 8 & 50 & 2.16 \\
E (11) & 38 & 12 & 50 & 0.03 \\
F (10) & 44 & 6 & 50 & $4.51^{*}$ \\
\hline
\end{tabular}

$*$ and $* * *$ : Significant at $5 \%$ and $0.1 \%$ levels, respectively.

From the results obtained, it is suggested that the genes for $13 \mathrm{~b}-\mathrm{L}$ in $\mathrm{CM}$ 21 and $57-\mathrm{H}$ in $\mathrm{CM} 1787$ are designated as $e s p-1$ and esp-2, respectively, in which esp stands for endosperm storage protein.

The endosperm is triploid, with two of the genes from the maternal parent. Gene dosage effect has been reported to occur in $\mathrm{F}_{1}$ and $\mathrm{F}_{2}$ seed storage protein 
in barley (Doll 1980), wheat (Burnouf et al. 1983, Dhaliwal 1977) and maize (Soave et al. 1981, Valentini et al. 1979). In the case of the mutant for the structural gene coding the polypeptide, the gene dosage effect, if any, should appeare in the polypeptides of $F_{1}$ and $F_{2}$ seeds. In this study, the two polypeptides, the $13 \mathrm{~b}$ and $57 \mathrm{kDa}$, showed no gene dosage effect (Fig. 1 and Fig. 2). On the other hand, in IEF and bidimensional electrophoresis (IEF/SDS) system, the intensity of some polypeptides in the protein composition of PB-I in CM 21 were reduced compared to that in Kinmaze (Kumamaru unpublished). These facts suggest that $e s p-1$ is a mutation of the regulatory gene for the polypeptides, being analogous to the case of the O2 gene in maize (Soave et al. 1978). It has been reported that glutelin is deposited in PB-II (Tanaka et al. 1980), and that subunit groups of glutelin, the 22 to $23 \mathrm{kDa}$ and the 37 to $39 \mathrm{kDa}$ polypeptides, are formed through post-translational modification of the $57 \mathrm{kDa}$ polypeptide (Yamagata et al. 1982, Yamagata and Tanaka 1986). Therefore, the enriched $57 \mathrm{kDa}$ and the reduced glutelin polypeptides in CM 1787 is supposed to be due to the abnormal processing of glutelin. For no gene dosage effect in $F_{1}$ and $F_{2}$ seeds, it is thought that esp-2 is not a structural gene but one of the genes for the post-translational processing of glutelin.

In conclusion, it is inferred that $e s p-1$ is a mutant of regulatory gene for the polypeptide of $\mathrm{PB}-\mathrm{I}$, and esp-2 is that for PB-II.

This work was partly supported with the Grant-in-Aid for Scientific Research (No. 59480027) from the Ministry of Education, Science and Culture, Japan.

\section{REFERENCES}

Blake, T. K., UllRich, S. E. and Nilan, R. A. (1982) Mapping of the Hor-3 locus encoding D hordein in barley. Theor. Appl. Genet. 63, 367-371.

Burnouf, T., Bouriquet, R. and Poullard, P. (1983) Inheritance of glutenin subunits in $F_{1}$ seeds of reciprocal crosses between european hexaploid wheat cultivars. Theor. Appl. Genet. 64, 103-107.

Dhaliwal, H. S. (1977) Genetic control of seed proteins in wheat. Theor. Appl. Genet. 50, 235239.

DoLL, H. (1980) A nearly non-functional mutant allele of the storage protein locus Hor2 in barley. Hereditas 93, 217-222.

FaUlKs, A. J., Shewry, P. R. and Miflin, B. J. (1981) The polymorphism and structural homology of storage polypeptides (hordein) coded by the Hor-2 locus in barley (Hordeum vulgare L.). Biochem. Genet. 19, 841-858.

Galili, G. and Feldman, M. (1984) Mapping of glutenin and gliadin genes located on chromosome 1B of common wheat. Mol. Gen. Genet. 193, 293-298.

Iwata, N., Omura, T. and Nakagahra, M. (1970) Studies on the trisomics in rice plants (Oryza sativa L.). I. Morphological classification of trisomics. Jpn. J. Breed. 20, 230-236.

Iwata, N. and Omura, T. (1971) Linkage analysis by reciprocal translocation method in rice plants (Oryza sativa L.). II. Linkage groups corresponding to the chromosomes 5, 6, 8, 9, 10 and 11. Sci. Bull. Fac. Agr., Kyushu Univ. 25, 137-153 (in Japanese with English summary).

Iwata, N. and Omura, T. (1975) Studies on the trisomics in rice plants (Oryza sativa L.). III. 
Relation between trisomics and genetic linkage groups. Jpn. J. Breed. 25, 363-368.

JACKson, E. A., Holt, L. M. and PAYNe, P. I. (1983) Characterisation of high molecular weight gliadin and low-molecular-weight glutenin subunits of wheat endosperm by two-dimensional electrophoresis and the chromosomal localisation of their controlling genes. Theor. Appl. Genet. 66, 29-37.

Kambayashi, M., Tsurumi, I. and Sasahara, T. (1984) Genetic studies on improvement of protein content in rice grain. Jpn. J. Breed. 34, 356-363 (in Japanese with English summary).

KATAOKA, K. (1978) Inheritance of grain-protein content in rice. Jpn. J. Breed. 28, 263-268 (in Japanese with English summary).

Kumamaru, T., Satoh, H., Omura, T., Ogawa, M. and Tanaka, K. (1986) Protein bodies of mutants for storage protein in rice endosperm. Jpn. J. Breed. 36 (Suppl. 1), 326-327 (in Japanese).

Kumamaru, T., Satoh, H., Iwata, N., Omura, T., Ogawa, M. and Tanaka, K. (1987) Mutants for rice storage proteins. I. Screening of mutants for rice storage proteins of protein bodies in the starchy endosperm. Theor. Appl. Genet. (submitted).

LAEMmLI, U. K. (1970) Cleavage of structural protein during the assembly of the head of bacteriophage T4. Nature 227, 680-685.

LEE, K. H., JONES, R. A., DALBY, A. and TSAI, C. Y. (1976) Genetic regulation of storage protein content in maize endosperm. Biochem. Genet. 14, 641-650.

PAYNe, P. I., LAW, C. N. and MUdD, E. E. (1980) Control by homoeologous group 1 chromosomes of the high-molecular-weight subunits of glutenin, a major protein of wheat endosperm. Theor. Appl. Genet. 58, 113-120.

Payne, P. I., Holt, L. M., Worland, A. J. and Law, C. N. (1982) Structural and genetical studies on the high-molecular-weight subunits of wheat glutenin. Part 3. Telocentric mapping of the subunit genes on the long arms of the homoeologous group 1 chromosomes. Theor. Appl. Genet. 63, 129-138.

Payne, P. I., JACKSON, E. A., Holt, L. M. and LAw, C. N. (1984) Genetic linkage between endosperm storage protein genes on each of the short arms of chromosomes $1 \mathrm{~A}$ and $1 \mathrm{~B}$ in wheat. Theor. Appl. Genet. 67, 235-243.

Shewry, P. R., Faulks, A. J., Pickering, R. A., Jones, I. T., Finch, R. A. and Miflin, B. J. (1980) The genetic analysis of barley storage proteins. Heredity 44, 383-389.

Shewry, P. R., Finch, R. A., Parmar, S., Franklin, J. and Miflin, B. J. (1983) Chromosomal location of Hor 3, a new locus governing storage proteins in barley. Heredity 50, 179-189.

Soave, C., Suman, N., Viotti, A. and Salamini, F. (1978) Linkage relationships between regulatory and structural gene loci involved in zein synthesis in maize. Theor. Appl. Genet. $52,263-267$.

Soave, C., Reggiani, R., Fonzo, N. D. and Salamini, F. (1981) Clustering of genes for $20 \mathrm{kd}$ zein subunits in the short arm of maize chromosome 7. Genetics 97, 363-377.

Soave, C., Reggiani, R., Fonzo, N. D. and Salamini, F. (1982) Genes for zein subunits on maize chromosome 4. Biochem. Genet. 20, 1027-1038.

TanaKa, K., Sugimoto, T., OGawa, M. and KaSAI, Z. (1980) Isolation and characterization of two types of protein bodies in the rice endosperm. Agric. Biol. Chem. 44, 1633-1639.

Valentini, G., Soave, C. and Ottaviano, E. (1979) Chromosomal location of zein genes in Zea mays. Heredity 42, 33-40.

Yamagata, H., Sugimoto, T., TANaKa, K. and Kasai, Z. (1982) Biosynthesis of storage proteins in developing rice seeds. Plant Physiol. 70, 1094-1100.

YAMAGATA, H. and TANAKA, K. (1986) The site of synthesis and accumulation of rice storage proteins. Plant Cell Physiol. 27, 135-145. 